\title{
LATE WISCONSINAN GLACIAL GEOMORPHOLOGY OF THE KENT INTERLOBATE COMPLEX, OHIO, USA
}

JOÃO BESSA SANTOS ${ }^{1}$

\begin{abstract}
The northern sector of the Kent Interlobate Complex, created by two major ice lobes of the Laurentide Ice Sheet during late Wisconsinan times, dominates the glacial landscape of northeast Ohio. The geomorphology of this impressive complex reveals the presence of large hummocks, kettle lakes and substantial esker chains. The esker chains, usually smaller than $1.3 \mathrm{~km}$ long, run parallel to the interlobate complex geographic orientation of northeast-southwest. Gravel pits present on large hummocks display bedded and sorted sedimentary units of gravel, sand and gravel and climbing ripple laminated sand with folds, which demonstrate that the northern sector of the interlobate complex is primarily a glaciofluvial feature. Topping these hummocks is a massive clast-supported diamicton interpreted to be a debris flow. These geomorphic and sedimentary characteristics seem to indicate that hummocks present in the interlobate area are in fact kames and that the entire northern sector of the interlobate complex is a product of late Wisconsinan time transgressive ice stagnation that occurred between two major ice lobes.
\end{abstract}

Keywords: Glacial geomorphology, interlobate complexes, northeast Ohio.

Resumo - GEOMORFOLOGIA GLACIÁRIA DO COMPLEXO INTERLOBULAR DE KENT, OHIO, NO FINAL DO WINSCONSINAN. O sector norte do Complexo Interlobular de Kent, criado por dois dos principais lóbulos de gelo do Inlandis de Laurentide durante o TardiWisconsinan, domina a paisagem glaciária do nordeste do Ohio. A geomorfologia deste complexo apresenta hummocks, kettle lakes e diversas cadeias de eskers. As cadeias de eskers, geralmente de comprimento inferior a $1.3 \mathrm{~km}$, possuem uma orientação nordeste-sudoeste, paralela à do complexo interlobular. Areeiros presentes nos hummocks apresentam unidades sedimentares calibradas de calhaus, de calhaus e areias intercaladas e de areias laminadas com climbing ripples e folds, que demonstram que o complexo interlobular é essencialmente uma forma fluvioglaciária. No topo dos hummocks verifica-se ainda a existência de um diamicton clasto-suportado interpretado como sendo um depósito de vertente. As características geomorfológicas e sedimentológicas dos hummocks presentes no complexo interlobular parecem indicar que os mesmos são na verdade kames e que todo o complexo é produto da estagnação glaciária transgressiva durante o Tardi-Wisconsinan entre dois lóbulos de gelo. 
Palavras-chave: Geomorfologia glaciária, complexos interlobulares, nordeste do Ohio.

Résumé - GÉOMORPHOLOGIE GLACIAIRE DU COMPLEXE INTERLOBAIRE DU KENT, OHIO, DURANT LE WISCONSINIEN TARDIF. Le secteur nord du Complexe Interlobaire de Kent, créé par deux des principaux lobes de glace de l'Inlandsis Laurentidien pendant le Wisconsinien tardif, domine le paysage glaciaire du nord-est de l'Ohio. La géomorphologie de ce complexe révèle la présence de hummocks, de kettles remplis d'eau et de plusieurs chaines d'eskers. Les chaines d'eskers, dont la longueur est généralement inférieure à 1,3 $\mathrm{km}$, sont orientées du nord-est au sud-ouest, parallèlement au complexe interlobaire. Les gravières qui se trouvent dans les hummocks présentent des unités sédimentaires litées et classées, du sable et des graviers, ainsi que des dépôts de sable stratifiés offrant des ondulations et des replis, ce qui montre que le secteur nord du complexe interlobaire est essentiellement une forme fluvioglaciaire. Dans la partie supérieure des hummocks se trouve un diamicton massif supporté par des clastes, interprété comme étant une coulée de débris. Les caractéristiques géomorphologiques et sédimentaires des hummocks présents dans le complexe interlobaire semblent indiquer que ceux-ci sont en fait des kames et que l'intégralité du secteur nord du complexe interlobaire est le produit de la stagnation glaciaire transgressive dans le temps qui aurait eu lieu pendant le Wisconsinien tardif entre deux lobes de glace.

Mots-clés: Géomorphologie glaciaire, complexes interlobaires, nord-est de l'Ohio.

\section{INTRODUCTION}

The study of glacial landforms and deposits is important, as it is difficult to observe processes occurring under modern glaciers and ice sheets. Thus, landscapes and sediments that are the product of past glaciations can give insight into processes that are occurring beneath modern glaciers.

This research investigates the genesis of the northern sector of a zone of hummocky terrain that is named here as the "Kent Interlobate Complex" (Santos, 2003). This complex is located in northeast Ohio (fig. 1a, fig. 1b) and was hypothesized by other researchers to have been formed between the Killbuck and Grand River Lobes of the Laurentide Ice Sheet during the late Wisconsinan stage (White, 1982; Hoper and Szabo, 1993; Szabo and Totten, 1995; Szabo and Bruno, 1997; Szabo et al., 2006). Interlobate complexes are important, mainly because they allow glacial geomorphologists to better understand the nature of ice sheet dynamics, especially the processes that occur in the ice-contact environment during ice retreat and stagnation.

The simplest definition of an interlobate complex is the accumulation of rock debris (till or stratified glaciofluvial sediments) between two adjacent glacial lobes (Easterbrook, 1999). Punkari (1980, 1997), based on the sedimentology of these features defined interlobate complexes as broad zones of mainly sand and gravel, arranged in almost continuous ridges and irregular mounds. 


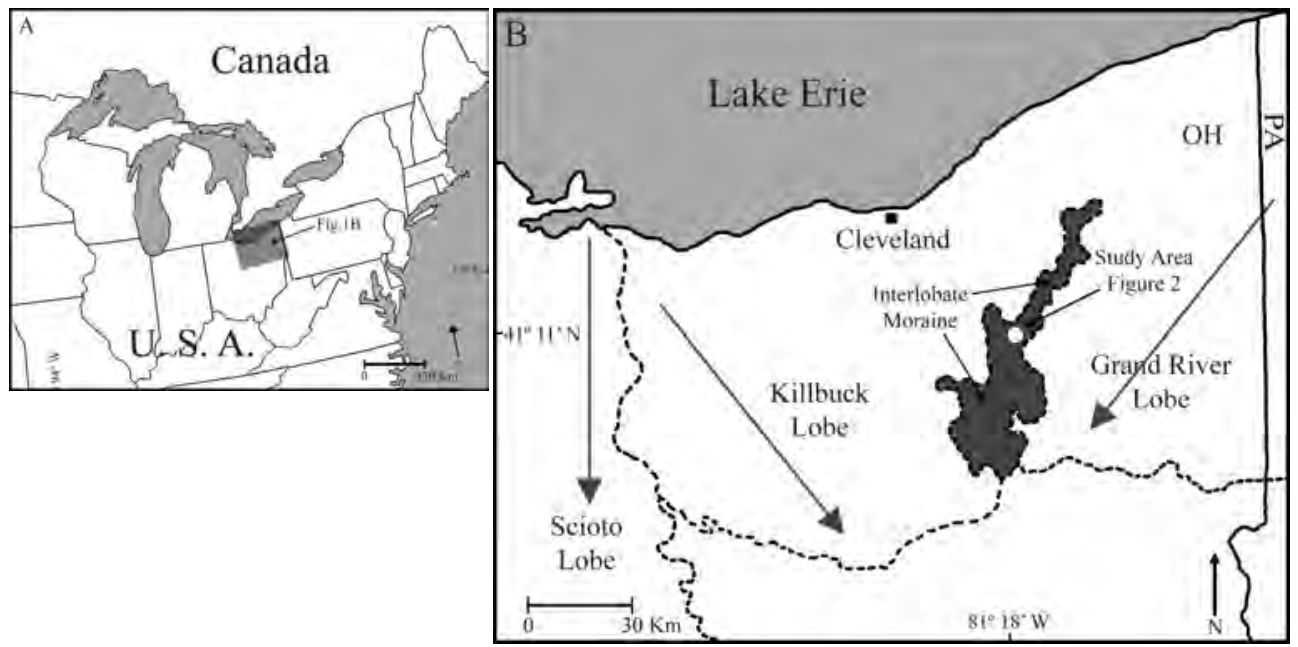

Fig. 1a - Study area in the Great Lakes region of North America.

Fig. 1a-Área de estudo na região dos Grandes Lagos da América do Norte.

Fig. $1 \mathrm{~b}$ - Location of the Kent Interlobate Complex in northeast Ohio. Gray lines show former ice flow directions of major lobes.

Fig. $1 b$-Localização do Complexo Interlobular de Kent, Nordeste do Estado do Ohio. As linhas a cinza demonstram antigas direcções do fluxo do gelo nos principais lóbulos.

However, despite these author's basic definitions, achieving a general concise definition for interlobate complexes is complicated because researchers usually have different classifications for these features based on their morphology. For example, Eyles et al. (1999) and Evans (2000) called the interlobate area of the Central and Eastern Lobes of the Laurentide Ice Sheet in Alberta, Canada a hummocky moraine. Karrow and Paloschi (1996) classified the Waterloo Moraine (in an interlobate area formed between the Erie and Simcoe Lobes in Ontario, Canada) as a kame moraine. This definition was also used by White (1982) to define the interlobate area between the Grand River and Killbuck Lobes in northeastern Ohio. Punkari (1997) classified the interlobate area of the Salpauselka and Central Finland margin lobes as an interlobate complex; however, despite these different terminologies, researchers generally agree that interlobate complexes are large areas of glaciofluvial sediments deposited during several periods of deglaciation (Price, 1973; Brennand and Shaw, 1996; Karrow and Paloschi, 1996; Punkari, 1997; Carlson et al., 2005; Santos, 2003, 2006).

\section{PREVIOUS MODELS OF THE GENESIS OF INTERLOBATE COMPLEXES}

The formation of these complexes is poorly understood. In particular, there is an ongoing debate over whether these form during a single synchronous glacial event with no significant changes in ice flow directions (Brennand and Shaw, 1996), or 
whether they form time-transgressively under a complex set of flow directions and changing ice front positions (Punkari, 1997; Carlson et al., 2005; Santos, 2003, 2006).

Black (1970) proposed a proglacial genesis model for the Northern Kettle Moraine, Wisconsin and suggested that the ridges bordering a low relief, central (interlobate) low area were thrust moraines formed during an advance that overrode proglacial sediment. Meltwater from the lobes drained across the ridges and southward, through channels in the central low area. Fraser (1993) proposed a similar genesis to an interlobate system in the Wabash Valley, Indiana, where proglacial meltwater from the Lake Michigan Lobe and Huron-Erie Lobe deposited sediment between the two lobes. Mickelson and Syverson (1997) and Carlson et al. (2005) envisioned a different model for the Northern Kettle Moraine in Wisconsin. They proposed that the two marginal ridges of the Northern Kettle Moraine were deposited in sub- or englacial tunnels and are large eskers. This partly supraglacial and partly subglacial genesis model has also been applied to explain interlobate deposits in the Scandinavian Ice Sheet by Punkari $(1980,1997)$. A subglacial genesis model was suggested by Brennand and Shaw (1996) for the Harricana glaciofluvial complex in Quebec, Canada. They compared sedimentary facies and structures from the Harricana complex to esker deposits and inferred that deposition in a conduit formed by a subglacial flood event could explain at least $250 \mathrm{~km}$ of the $1000-\mathrm{km}$-long complex (Carlson et al., 2005).

Examination of the northern sector of the Kent Interlobate Complex will determine if its origin is comparable to proposed models that explain the genesis of these features. Specifically, the Kent Interlobate Complex has been studied little. Most of the research conducted in this feature was undertaken by White (1982), who defined it as a zone of hummocky topography. White (1982) did extensive work in dating the tills of the Grand River and Killbuck Lobes but there is still a great need in analysing in detail the geomorphology and sedimentology of this feature in order to understand its genesis.

\section{SETTING}

The portion of northeastern Ohio where the interlobate complex is located (fig. 1a, fig. 1b) is part of the Allegheny Plateau. Its elevation in northeastern Ohio ranges from 320 meters to 365 meters. The oldest bedrock exposed in this region is a small outcrop of Devonian shale that occurs in a narrow belt along the shores of Lake Erie. Most of the bedrock outcrops are Mississippian and Pennsylvanian in age. The Mississippian rocks are siltstones, fine sandstones, and shales and are best exposed across the western portion of northeastern Ohio. The Pennsylvanian strata are conglomerates, sandstones, shales, limestones and coal beds and are best seen in the southern parts of the glaciated portion of the region.

Overlying the bedrock geology in this region is a series of Pleistocene glacial deposits from the last two glacial stages (Szabo et al., 2006). During the Pleistocene, 
particularly in the Illinoian and Wisconsinan stages, glacial ice entered northeastern Ohio from a center in Labrador and spread southwest down the Erie Basin creating the Erie Lobe in northeastern Ohio (Hoper and Szabo, 1993). Due to local bedrock topographic highs, the Erie Lobe divided into multiple sub-lobes (Hoper and Szabo, 1993; Szabo et al., 2006) that advanced into northeastern Ohio in different directions. The two main sub-lobes in this area were the Grand River and the Killbuck Lobes (fig. 1b).

\section{METHODOLOGY}

The northern sector of the Kent Interlobate Complex contains an array of landforms that are important for understanding the palaeo-ice processes and dynamics that contributed to its formation. Reconstruction of the processes responsible for the genesis of this feature was accomplished using geomorphic and sedimentologic techniques. Glacial features present in the interlobate region were identified by type, shape, size, orientation and slope through the use of digital elevation models, topographic maps and aerial photographs.

Sedimentary logging, clast analysis, grain size analysis and palaeoflow analysis were used to reconstruct meltwater-flow directions and the depositional history of the northern sector of the interlobate complex. Logging of sedimentary units present in exposures included the identification of bedforms, structures and lithofacies using Miall (1978) and Eyles et al. (1983) lithofacies coding scheme. Clast analysis was accomplished in the field by determining clast sphericity and roundness. The shapes of clasts were determined using the classification of Zingg (1935) and roundness was estimated using the classification of Folk (1955). Meltwater-flow directions values were obtained in the field by measuring the down dip orientation of beds (ripple and dune cross-beds) present in sedimentary units. Values were further plotted on rose diagrams to calculate flow orientations using the software program Stereonet (version 5.1).

Grain size distributions were described using the Wentworth-Udden grain size classification (Udden, 1898; Wentworth, 1922) and the phi scale $(\phi)$ of Krumbein (1934). The grain size analysis was performed using sieves. This was undertaken on the matrix component of a sample only, where granules and pebbles $(-3.0 \phi)$ are the coarsest grain size. Thus, all samples were sieved through a $9.51 \mathrm{~mm}$ sieve prior to performing sieve analysis. A visual estimate of the coarse component $(>-3.0 \phi)$ was estimated in the field, using the charts of Harrell (1984). The grain size and paleocurrent laboratory analysis was performed in the departments of geography and geology at Kent State University, Ohio.

\section{GLACIAL GEOMORPHOLOGY}

The northern sector of the Kent Interlobate Complex was the region chosen to study the genesis of this feature. The overall interlobate complex is approximately 
$80 \mathrm{~km}$ long and 10 to $25 \mathrm{~km}$ wide (fig. $1 \mathrm{~b}$ ). Research was concentrated on a selected area of the interlobate complex in the vicinity of two large sand and gravel pits on either side of State Route 14 in Portage County (fig. 2): the Cruise Pit and the Beck Pit. They are located northeast of the city of Kent and southeast and northeast of State Route 14 bridge over Lake Rockwell (fig. 2).

Overall, hummocks, kettle lakes and eskers are the most impressive and common glacial landforms present in this portion of the interlobate complex. These landforms were mostly created during the late Wisconsinan stage (Hoper and Szabo, 1993 ) and are very well preserved.

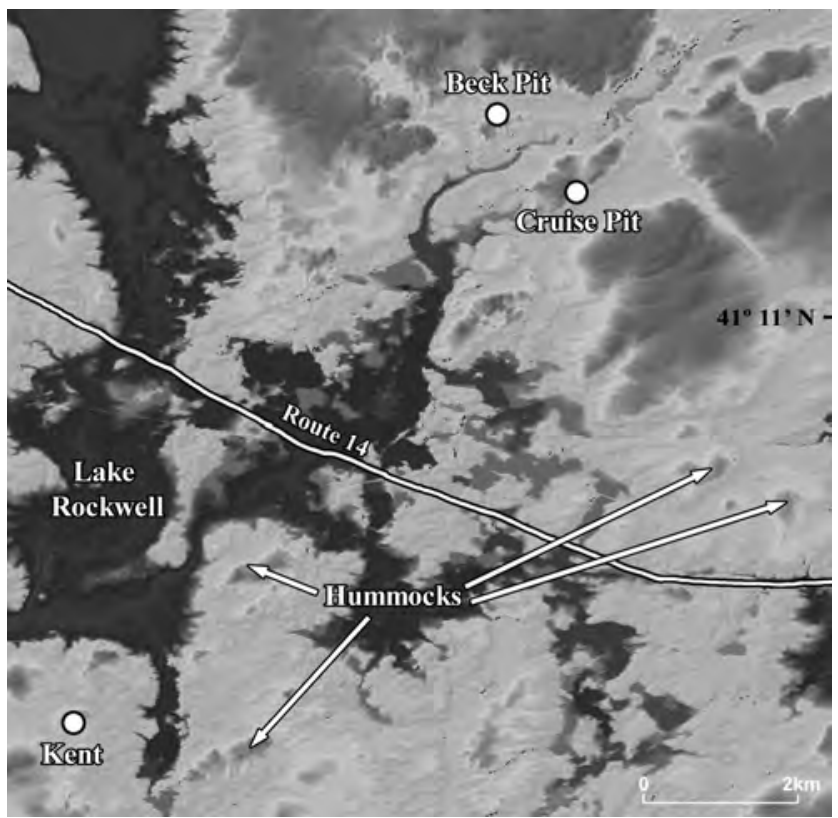

Fig. 2 - Digital elevation model showing the location of gravel pits on the northern sector of the Kent Interlobate Complex.

Fig. 2 - Modelo digital de terreno monstrando a localização dos areeiros analisados no sector norte do Complexo Interlobular de Kent.

\section{Hummocks}

Hummocky terrain is the most conspicuous topography present in the region of the interlobate complex. These mounds have average elevations of between 15 to 20 meters (fig. 3). Hummocks in this region of the interlobate complex have a northeastern-southwestern orientation. This shows that ice from the large Erie Lobe must have entered northeastern Ohio from the northeast. These hummocks tend to be asymmetric in cross-section, circular in plan view, and have gentle slopes (fig. 2). For the most part they are organized in hummock chains with eskers and kettle lakes being also present. Eskers tend to run parallel to the hummock chains. 


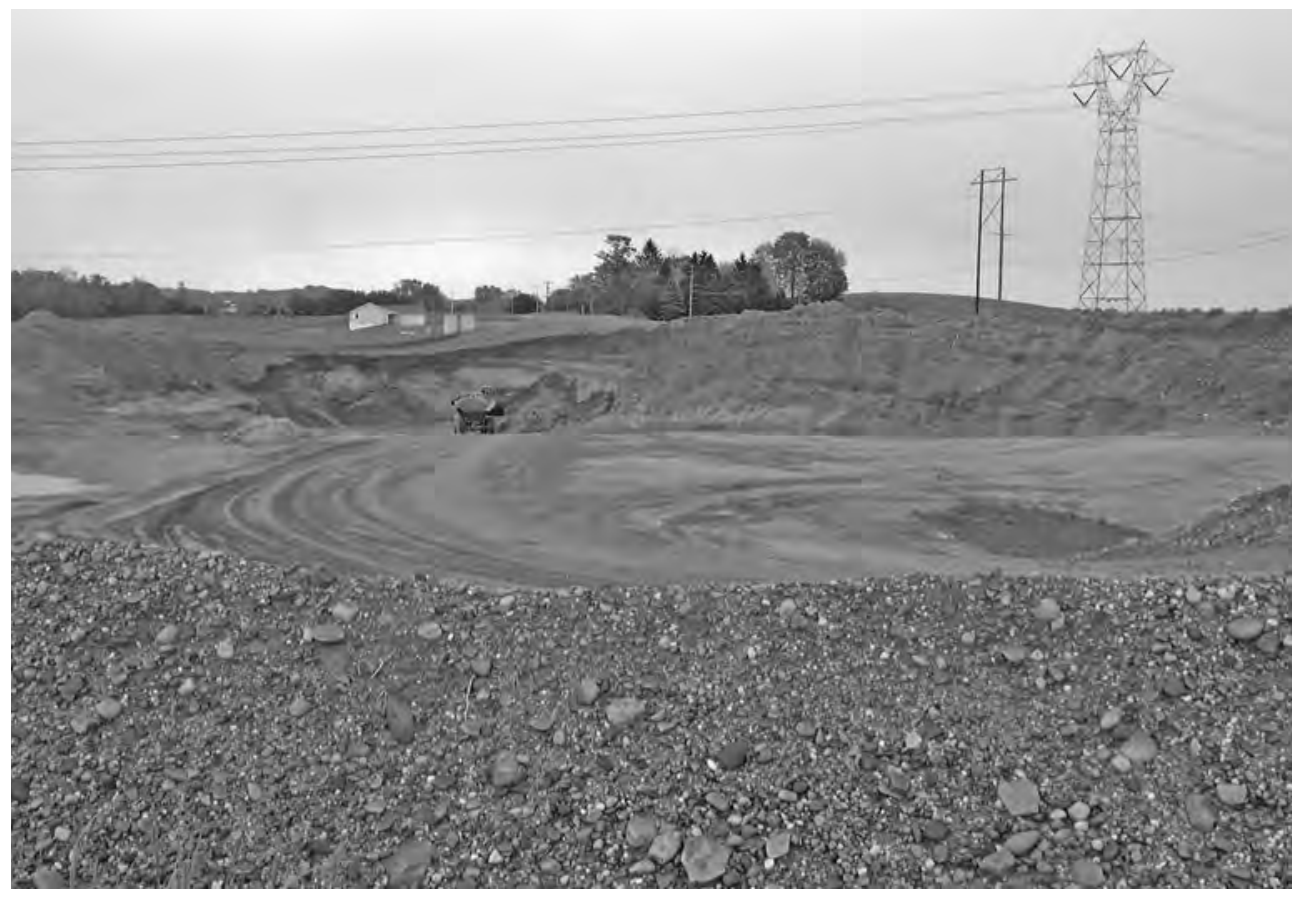

Fig. 3 - Large hummocks near the Beck Pit.

Fig. 3 - Hummocks de grande dimensão perto do Areeiro de Beck.

\section{Eskers and Kettle Lakes}

Eskers are very rare features in the northern sector of the Kent Interlobate Complex and usually occur as incomplete esker chains. They are short in length (approximately $1.3 \mathrm{~km}$ long) and occur in association with hummocks and kettle lakes. The main esker chains in the northern sector of the interlobate complex are located near the city of Kent. They occur as short sinuous ridges with broad crests and have a preferred northeastern to southwestern orientation (fig. 4). These eskers are somewhat parallel to each other and based on their geomorphology can be classified as type II and III eskers (Brennand, 2000). They exhibit both sub-parallel orientations (type II) and deranged orientations (type III). They are composed of a short ridge and according to the Brennand (2000) classification they must have been formed in R-channels (subglacial channels incised upwards into the ice) or reentrants that terminated in standing water.

Small and large kettle lakes are also abundant ice-contact glacial landforms present in the northern sector of the Kent Interlobate Complex. Some examples of the largest kettle lakes present in the study area are East Twin (approximately 800 meters long and 550 meters wide) and West Twin (approximately 600 meters long and 550 meters wide) Lakes located in the vicinity of the city of Kent (fig. 4). 


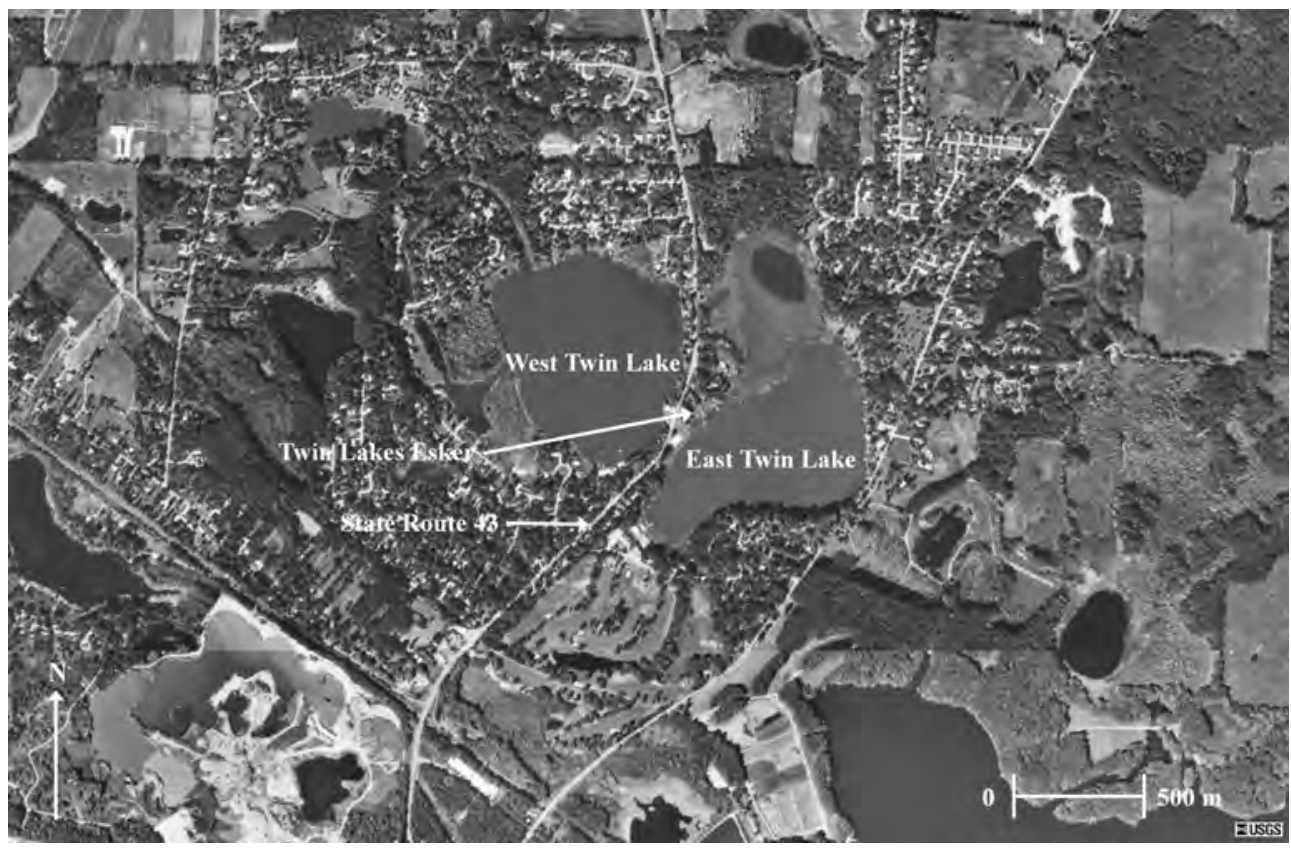

Fig. 4 - Aerial photograph showing the Twin Lakes Esker and East and West Twin Lakes near the city of Kent.

Fig. 4 - Fotografia aérea mostrando a localização do Esker de Twin Lakes e dos Lagos de East and West Twin perto da cidade de Kent.

\section{SEDIMENTOLOGY AND STRATIGRAPHY}

In order to understand the genesis of glacial landforms it is crucial to look at their sedimentology and stratigraphy as well as geomorphology (Benn and Evans, 1998). Therefore, in the study area, four sediment exposures in two large sand and gravel pits present in hummocks were analyzed. These are the Cruise and Beck Pits situated on State Route 14, Portage County in northeastern Ohio (fig. 2). For each exposure, sedimentary beds were described and interpreted.

\section{Cruise Pit Description}

\subsection{Exposure 1}

Cruise Pit exposure 1 is approximately 5.5 meters high and is composed of five sedimentary units. One generalized sedimentary log was plotted in order to describe the entire sedimentary sequence present in this exposure (fig. 5).

The five sedimentary units are described from the oldest to the youngest. Unit 1 is $60 \mathrm{~cm}$ thick and is composed of moderately sorted (standard deviation around 
0.99) plane bedded (lithofacies Sh) yellowish-brown fine sands (table I, fig. 5) with a unimodal distribution.

Unit 1 grades into unit 2, which is $30 \mathrm{~cm}$ thick and composed of moderately sorted (standard deviation around 0.98) climbing ripple laminated (lithofacies Scr) yellowish-brown medium to fine sands (table I, fig. 5) with a unimodal distribution. Palaeoflow from the undisturbed regions of this unit shows a mean orientation of $339^{\circ}$ (table I), therefore when deposition occurred in this unit the flow direction was roughly from the northwest to the southeast (fig. 5). The contact between units 1 and 2 is somewhat folded into a syncline-like feature (fig. 5).

Unit 3 abruptly overlies unit 2. It is $90 \mathrm{~cm}$ thick and is composed of poorly sorted (standard deviation around 1.93) horizontally bedded (lithofacies GRh) yellowish-brown interbedded coarse sand and gravel (table I, fig. 5) with a bimodal distribution. The granules and pebbles present in this unit are sub-rounded to rounded. Palaeoflow from the undisturbed regions of unit 3 shows a mean orientation of $346^{\circ}$ (table I), which means that flow direction was again roughly from the northwest to the southeast (fig. 5) when unit 3 was deposited.

Unit 4 abruptly overlies unit 3 and is approximately 2.5 meters thick. It is composed of horizontally bedded gravels (lithofacies Gh) (fig. 5). Pebbles and cobbles on this unit are sub-rounded to rounded. It was not possible to collect samples from this unit due to safety regulations imposed by the gravel pit owner.

Finally at the top of exposure 1 is unit 5, the contact between unit 4 and unit 5 is also abrupt. The unit is about 1.2 meters thick and is composed of a massive clast-supported diamicton (lithofacies Dcm) (fig. 5). It was also not possible to collect samples from this unit due to safety regulations.

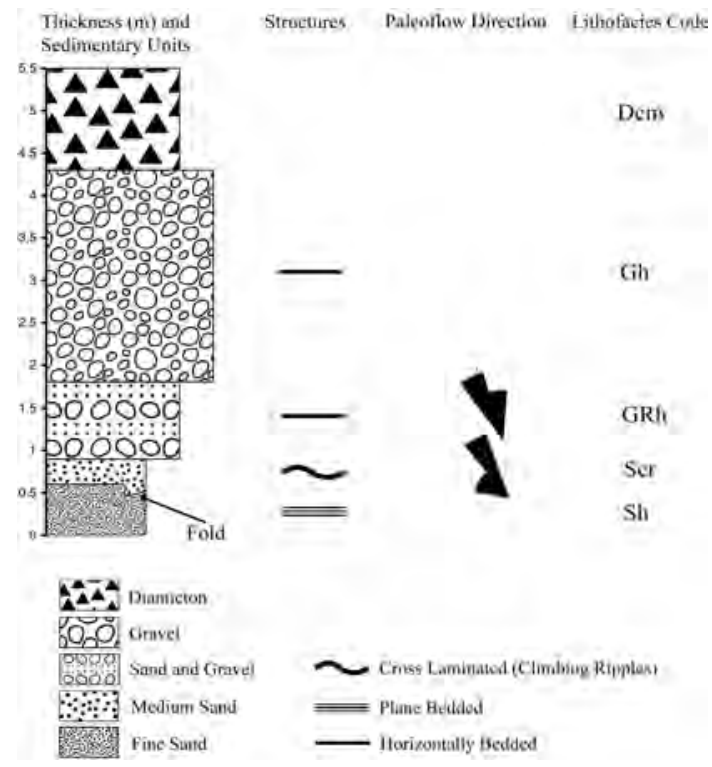

Fig. 5 - Cruise Pit exposure 1 sedimentary log.

Fig. 5 - Unidades sedimentares no corte 1 do Areeiro de Cruise. 
Table I - Sample locality and sedimentologic data.

Quadro I - Locais de amostragem e respectivos dados sedimentológicos.

\begin{tabular}{|c|c|c|c|c|c|c|c|c|c|}
\hline \multirow[b]{2}{*}{ Site } & \multirow[b]{2}{*}{ Exposure } & \multirow[b]{2}{*}{ Unit } & \multicolumn{7}{|c|}{ Grain Size } \\
\hline & & & Gravel ${ }^{a}$ & Sand & Mud $^{b}$ & $\begin{array}{c}\text { Graphic } \\
\text { Mean }\end{array}$ & $\begin{array}{l}\text { c Standard } \\
\text { Deviation }\end{array}$ & $\begin{array}{c}\text { Sample } \\
\text { Number (n) }\end{array}$ & $\begin{array}{l}\text { Vector } \\
\text { Mean }\end{array}$ \\
\hline Cruise Pit & 1 & 1 & 0.44 & 96.22 & 3.34 & 2.22 & 0.99 & na & na \\
\hline Cruise Pit & 1 & 2 & 1.35 & 97.11 & 1.54 & 1,90 & 0.98 & 6 & 339 \\
\hline Cruise Pit & 1 & 3 & 21.87 & 74.97 & 3.16 & -0.30 & 1.93 & 6 & 346 \\
\hline Cruise Pit & 2 & 1 & 0.40 & 98.60 & 1.00 & 1.13 & 0.99 & 14 & 310 \\
\hline Cruise Pit & 2 & 2 & 1.51 & 95.91 & 2.58 & 1.98 & 0.98 & 10 & 310 \\
\hline Cruise Pit & 2 & 3 & 20.22 & 76.25 & 3.53 & -0.20 & 2.00 & 6 & 316 \\
\hline Beck Pit & 1 & 1 & 0.66 & 96.46 & 2.88 & 1.98 & 0.97 & 20 & 40 \\
\hline Beck Pit & 1 & 2 & 28.39 & 68.15 & 3.46 & -0.90 & 1.77 & na & na \\
\hline Beck Pit & 2 & 1 & 1.09 & 96.13 & 2.78 & 1.85 & 0.97 & 19 & 8 \\
\hline Beck Pit & 2 & 2 & 19.97 & 76.25 & 3.78 & 0.07 & 2.09 & ná & na \\
\hline
\end{tabular}

\subsection{Exposure 2}

Exposure 2 is approximately 2 meters high and one sedimentary log was plotted in order to describe the entire sedimentary sequence present in this exposure (fig. 6). Three sedimentary units are present in the exposure.

Unit 1 is $40 \mathrm{~cm}$ thick and is composed of moderately sorted (standard deviation around 0.99) plane bedded (lithofacies Sh) yellowish-brown medium to fine sands (table I, fig. 6) with a unimodal distribution. Palaeoflow from the undisturbed regions of this unit shows a mean orientation of $310^{\circ}$ (table I), therefore when deposition occurred in this unit the flow direction was roughly from the northwest to the southeast (fig. 6).

Unit 1 grades into unit 2, which is $50 \mathrm{~cm}$ thick and composed of moderately sorted (standard deviation around 0.98) climbing ripple laminated (lithofacies Scr) yellowish-brown medium to fine sands (table I, fig. 6) with a unimodal distribution. Palaeoflow from the undisturbed regions of this unit shows also a mean orientation of $310^{\circ}$ (table I), which means that flow direction, was roughly from the northwest to the southeast (fig. 6).

Unit 3 along an erosional contact overlies unit 2. This unit is 1.1 meters thick and is composed of poorly sorted (standard deviation of aproximatley 2.00) horizontally bedded (lithofacies GRh) yellowish-brown interbedded coarse sand and gravel (table I, fig. 6) with a bimodal distribution. The granules and pebbles of this unit are sub-rounded to rounded. Palaeoflow from the undisturbed regions of unit 3 shows a mean orientation of $316^{\circ}$ (table I), which means that flow direction was also roughly from the northwest to the southeast (fig. 6) when unit 3 was deposited. 


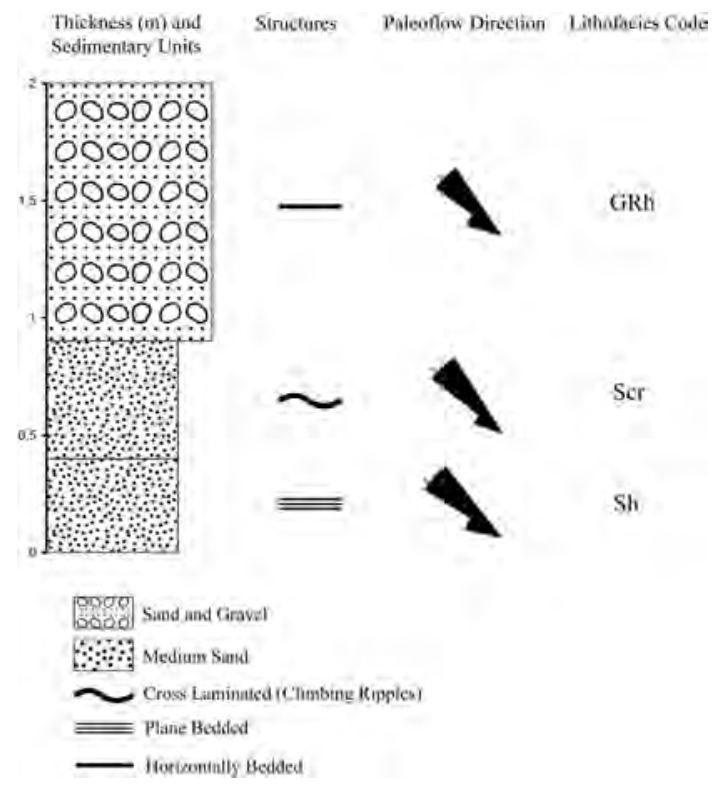

Fig. 6 - Cruise Pit exposure 2 sedimentary log.

Fig. 6 - Unidades sedimentares no corte 2 do Areeiro de Cruise.

\section{Cruise Pit Interpretation}

In summary, sediments present in both exposures are bedded, laminated, moderately to poorly sorted and have abrupt changes in particle size and sedimentary structures. These characteristics are generally typical of glaciofluvial deposits (Fahnestock, 1963; Church, 1972; Church and Ryder, 1972; Church \& Gilbert, 1975; Smith, 1985; Easterbrook, 1999). Several depositional events are recorded in the different units present in these exposures. These are reconstructed from the bottom to the top.

The plane bedded medium to fine sands present in unit 1 of both exposures were deposited under the presence of a weak flow regime capable of producing lower flow regime plane beds. These can be explained by minor fluctuations in flow velocity and sediment supply (Nichols, 1999). After this first depositional event flow regime must have increased and deposited the climbing ripple laminated medium to fine sands present in unit 2 of both exposures. The presence of climbing ripples in unit 2 is explained by a relative low water flow velocity associated with a large quantity of sediment for transportation (Jopling and Walker, 1968; Allen, 1970, 1971, 1973, 1985). This type of sedimentary structure (lithofacies Scr) (Miall, 1978) is commonly present on proglacial (Ashley et al., 1982), supraglacial and subglacial settings due to the presence of large sediment accumulations and cyclical variations in meltwater flow. 
The folding of units 1 and 2 present in exposure 1 is indicative of shear stress imposed on the beds after their deposition. This shear stress was caused either by glacial advance over these sediments or by substantial slumping that happened after the deposition of these sediments. These sands units most likely were deposited in crevasses or supraglacial and englacial channels by meltwater streams when ice retreated prior to hummock formation. Slumping that caused folding in these units must have occurred when ice that supported these sediments in crevasses or channels became stagnant and melted in situ.

After the deposition of unit 2, flow increased in velocity and deposited the interbedded sands and gravels present in unit 3 of both exposures. These beds indicate also that flow competence was significantly higher than for the lower beds. The presence of unit 4 on exposure 1 (absent on exposure 2 probably due to removal by mining) marks a significant major change in flow characteristics. Velocities increased significantly, which is evidenced by the presence of horizontally bedded gravels without cross-bedding. The transition from sand beds to interbedded sand and gravel beds and finally to gravel beds represents variations in stream power or sediment availability in specific areas of the streambed (Nichols, 1999). Such transitions are often explained by variations in meltwater that occur diurnally as well as seasonally (Smith, 1985) which are characteristic of proglacial, subglacial, englacial and supraglacial drainage systems. The presence of horizontally bedded gravels without significant cross-bedding also suggests that deposition must have occurred under the presence of sheetflow conditions during a minor flood episode.

After this major event, flow regime decreased significantly. Unit 5, composed of a massive clast-supported diamicton (lithofacies Dcm) that overlies unit 4 in exposure 1 , is interpreted to be a debris flow that was deposited by substantial slumping after the deposition of unit 4 occurred. This depositional event most likely occurred during the melting and collapsing of an ice-walled cavity or tunnel covered by debris.

\section{Beck Pit Description}

\subsection{Exposure 1}

Beck Pit exposure 1 is approximately 5 meters high. One sedimentary log was also plotted in order to describe the two sedimentary units present in the exposure (fig. 7).

The bottom 1.2 meters of the exposure were covered with the debris from mining and quarrying, so it was impossible to sample and analyze the sedimentology of any existing units buried under the debris. Unit 1 is approximately 1 meter thick and is composed of moderately sorted (standard deviation of 0.97) climbing ripple laminated (lithofacies Scr) yellowish-brown medium to fine sands (table I, fig. 7) with a unimodal distribution. Palaeoflow from the undisturbed regions of this unit 
shows a vector mean of $40^{\circ}$ (table I), therefore when deposition occurred in this unit the flow direction was roughly from the northeast to the southwest (fig. 7).

Unit 1 is overlain by unit 2 along an erosional contact. This unit is 2.8 meters thick and is composed of poorly sorted (standard deviation of aproximatley 1.77) horizontally bedded (lithofacies Gh) gravels (table I, fig. 7) with a bimodal distribution. The pebbles in this unit are sub-rounded to rounded.

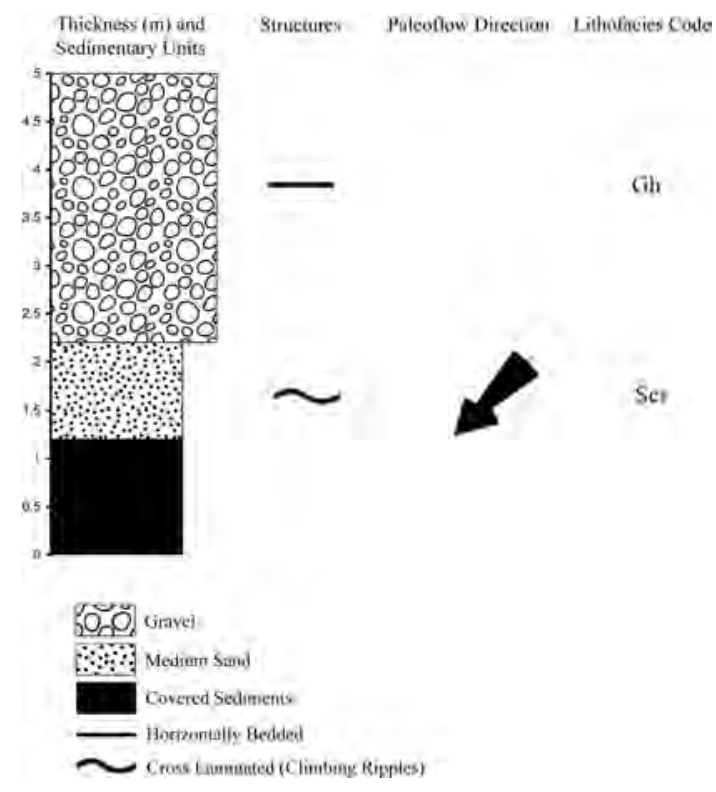

Fig. 7 - Beck Pit exposure 1 sedimentary log.

Fig. 7 - Unidades sedimentares no corte 1 do Areeiro de Beck.

\subsection{Exposure 2}

Exposure 2 is approximately 2.6 meters high and is composed of two distinct sedimentary units (fig. 8). One sedimentary log was plotted to describe the two units present in the exposure (fig. 9).

Unit 1 is approximately 1.2 meters thick and is composed of moderately sorted (standard deviation of 0.97) climbing ripple laminated (lithofacies Scr) yellowishbrown medium to fine sands (table I, fig. 8, 9, 10) with a unimodal distribution. Palaeoflow measurements from this unit show a mean orientation of $8^{\circ}$ (table I), which demonstrates that when deposition occurred in this unit, flow direction was roughly from the north-northeast to the south-southwest (fig. 9).

Similar to the exposure 1 , unit 1 is overlain by unit 2 along an erosional contact. This unit is 1.4 meters thick and is also composed of poorly sorted (standard deviation of 2.09) horizontally bedded (lithofacies Gh) gravels (table I, fig. 8,9) with a bimodal distribution. The pebbles in this unit are sub-rounded to rounded. 


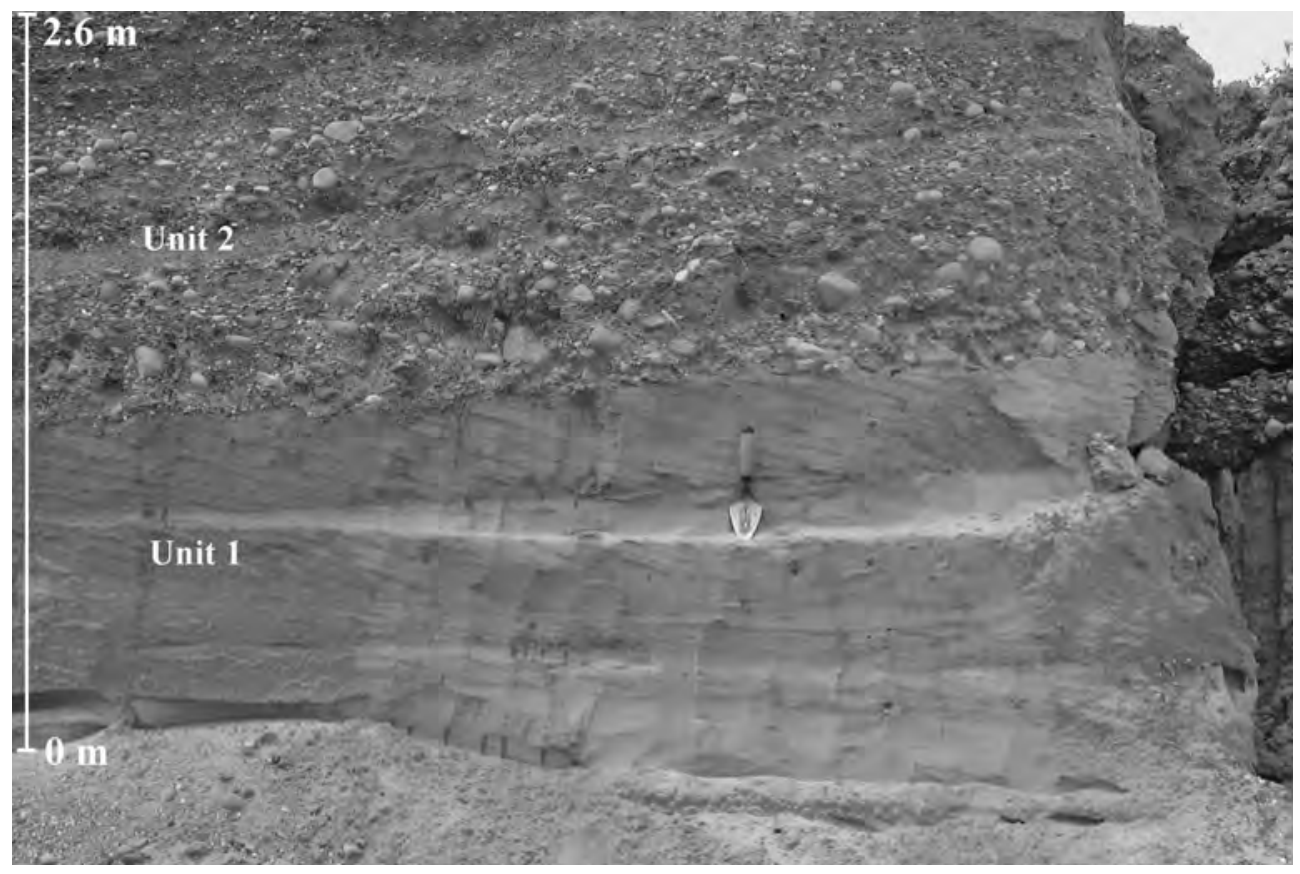

Fig. 8 - Beck Pit exposure 2 and sedimentary units 1 and 2 .

Fig. 8 - Unidades sedimentares 1 e 2 presentes no corte 2 do Areeiro de Beck.

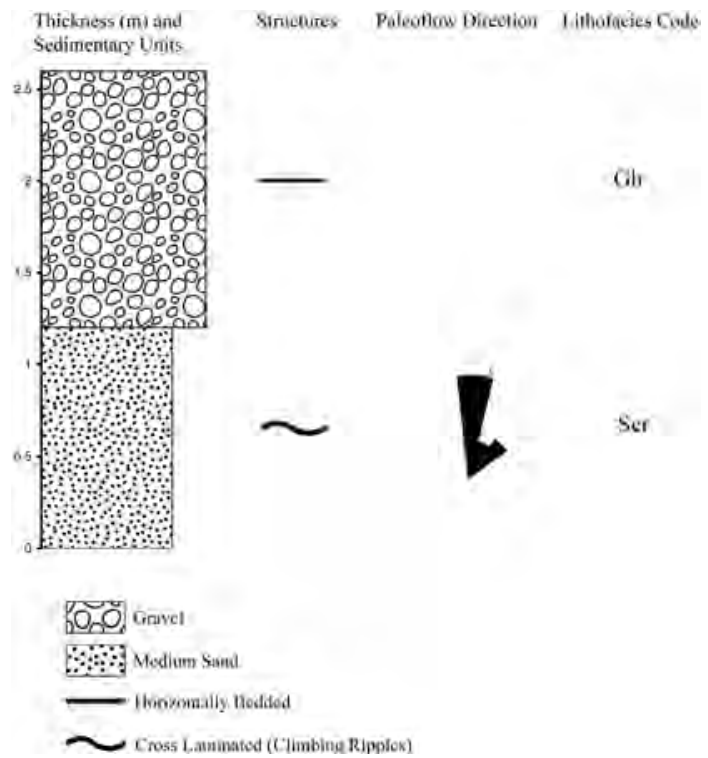

Fig. 9 - Beck Pit exposure 2 sedimentary log.

Fig. 9 -Descrição das unidades sedimentares no corte 2 do Areeiro de Beck. 


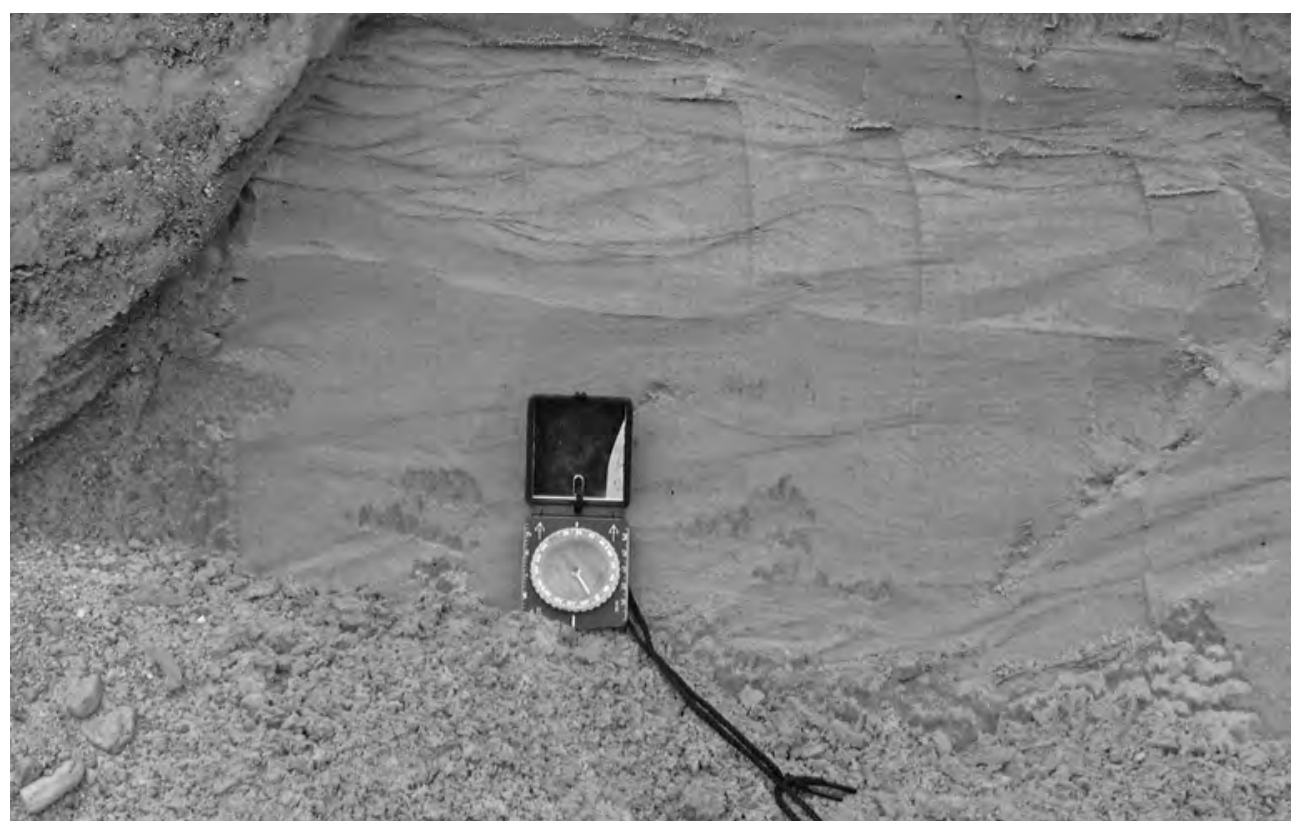

Fig. 10 - Beck Pit climbing ripple laminated sands in unit 1 of exposure 2.

Fig. 10 - Areias com laminação e climbing ripples presentes na unidade 1 do corte 2 do Areeiro de Beck.

\section{Beck Pit Interpretation}

The interpretation of the Beck Pit sedimentary units depositional history is similar to the interpretation proposed for the Cruise Pit. Given that sediments in both exposures 1 and 2 are moderately to poorly sorted and have abrupt changes in particle size and sedimentary structures, like all exposures described thus far, these are also presumed to be glaciofluvial in origin (Fahnestock, 1963; Church, 1972; Church and Ryder, 1972; Church \& Gilbert, 1975; Smith, 1985; Easterbrook, 1999).

The units record several depositional events. The presence of climbing ripple laminated medium to fine sands in unit 1 of both exposures is explained by a relative low water flow velocity associated with a large quantity of sediment for transportation (Allen, 1970, 1971, 1973, 1985). As was previously explained this type of sedimentary structure (lithofacies Scr) is a common feature in proglacial (Ashley et al., 1982), supraglacial and subglacial settings due to the presence of large sediment supply and cyclical variations in meltwater flow.

After the deposition of unit 1, flow velocities must have increased significantly, which are evidenced by the presence of horizontally bedded gravels in unit 2 of both exposures. The transition from climbing ripple laminated sand beds to gravel beds probably represents important variations in stream power or sediment availability in specific areas of the streambed. Once more these transitions can be explained by 
variations in meltwater supply that occur diurnally as well as seasonally in proglacial, subglacial, englacial and supraglacial drainage systems. The presence of horizontally bedded gravels with sub-rounded to rounded pebbles and without significant cross-bedding suggests deposition under sheetflow conditions most likely during the presence of minor flood conditions.

\section{DISCUSSION}

Hummocky terrain is the most common feature observed on the landscape of the northern sector of the Kent Interlobate Complex and thus its genesis is important for understanding the origin of this interlobate area. In the past twenty-five years, several researchers have explained the genesis of hummocky terrain present in interlobate and terminal areas of former North American Pleistocene ice sheets. Rieck (1979) proposed that hummocky terrain present on an interlobate area in Michigan is the product of ice stagnation that occurred when the Laurentide Ice Sheet was receding to the north. In the same manner, Mickelson and Syverson (1997), Eyles et al. (1999), Boone and Eyles (2001) and Carlson et al. (2005) also proposed that hummocky terrain present in glaciated areas of the former Laurentide Ice Sheet in North America is the product of ice wastage/stagnation. Munro and Shaw (1997) have challenged these ideas by proposing a glacial meltwater erosional origin for hummocky terrain present in south-central Alberta, Canada. More recently Fisher and Taylor (2002) and Fisher et al. (2003) also proposed a glacial meltwater depositional origin for hummocks present in south-central Michigan, U.S.A.

In this research it is proposed a time-transgressive ice stagnation origin for the northern sector of the Kent Interlobate Complex. It is also proposed that hummocks present in the interlobate area are kame deposits that associated with kettles lakes form a typical kame-kettle topography (Benn and Evans, 1998). Evidence for this hypothesis was found both in the morphology and sedimentology of the hummocks.

First, hummocks in the studied area show folds (Cruise Pit exposure 1, units 1 and 2) in their sedimentary units that can be explained by shear stress imposed on these beds after their deposition due to slumping events. These units must have been deposited in crevasses or supraglacial and englacial channels by meltwater streams (Johnson, 1975). Slumping that caused folding must have occurred when ice supporting these sediments in crevasses or channels became stagnant and melted. Folding in ice-contact sediments is a common characteristic of kame and stagnant ice deposits (Hambrey, 1984; Brodzikowski and Van Loon, 1991).

Second, the presence of a significant number of kettle lakes associated in most cases with hummocks composed of bedded and folded sand and gravel units is indicative of the presence of a kame and kettle topography created by stagnant ice (Benn and Evans, 1998).

Third, all sedimentary units present in these hummocks are composed of moderately to poorly sorted sediments. This is a common characteristic of stagnant ice 
sediments such as kame deposits where short distances of sediment transported in supraglacial and englacial channels produce moderately to poorly sorted sedimentary units (Easterbrook, 1999; Nichols, 1999). The transportation distance of these ice-contact sediments in the interlobate area between the Killbuck and Grand River Lobes was less than $30 \mathrm{~km}$ and explains the moderately to poorly sorted sediments. The pebbles present in the hummocks interbedded sand and gravel and gravel units are generally sub-rounded, which also supports a short sediment transportation history in the interlobate area (Sugden and John, 1976; Easterbrook, 1999).

Fourth, the presence of sand units in the hummocks with a lithofacies code Scr (climbing ripples) indicates the presence of a depositional environment with a low flow regime associated with large quantities of sediment for transportation. These sand units are common in supraglacial and englacial stagnant ice hydrologic and sedimentary regimes where high sedimentary budgets and variations in meltwater supply occur diurnally as well as seasonally (Smith, 1985).

Fifth, the fact that eskers and esker chains present in the interlobate area are short features (less than $1.3 \mathrm{~km}$ long) indicates that their deposition was also timetransgressive, which supports deposition under stagnant ice conditions. Punkari (1997) proposed a time-transgressive or episodic genesis for the interlobate area between the Salpauselka and Central Finland Lobes based on the fact that eskers in this feature are also short and segmented glacial landforms.

Sixth and last, the presence of bedded sand (lithofacies Sh and Scr), sand and gravel (GRh) and gravel (Gh) lithofacies sequences with variable internal geometry and overlaid by a massive clast-supported diamicton (lithofacies Dcm) represents the internal stratigraphy that is commonly present in kames (Huddart, 1983). The presence of the massive clast-supported diamicton, interpreted to be a debris flow, toping exposure one in the Cruise Pit is another indication of the presence of kame deposits and stagnant ice. These debris flows occurred when supraglacial sediments, released by the melting of ice and without fluvial reworking, suffer significant disturbance due to the melting and subsequent collapsing in situ of stagnant ice. These supraglacial deposits without fluvial reworking were deposited directly into crevasses via gravity flows and topped previously deposited bedded sand and gravel kame units as stagnant ice from the Killbuck and Grand River Lobes melted and collapsed at the end of the Wisconsinan stage.

\section{CONCLUSION}

In this research it is proposed a late Wisconsinan time-transgressive ice stagnation genesis for the northern sector of the Kent Interlobate Complex. This assumption is based on the geomorphology, sedimentolgy and internal stratigraphy of hummocks present in the studied area.

The stratigraphic sequences present in the studied hummocks show evidence of the presence of a melting stagnant ice mass. The lower units composed of climbing 
ripple-laminated sands were deposited by lower flow regimes under the presence of large sediment quantities. This type of deposition is typical with the beginning of melting in stagnant ice masses where sediment delivery by melting is higher than meltwater flow (Benn and Evans, 1998). The upper sand and gravel and gravel units were deposited when increased melting during the final stages of stagnant ice wastage released enough meltwater to transport larger clast sizes. Finally, the massive clast-supported diamicton (debris flow) overlaying the gravel units was deposited when supraglacial sediments present on the top of the ice fell into crevasses and moulins as stagnant ice melted and collapsed.

\section{ACKNOWLEDGMENTS}

I would like to express my sincere thanks to the scientific referees of this article for their insights and suggestions that greatly improved the scientific quality of the article.

\section{BIBLIOGRAPHY}

Allen J (1985) Principles of physical sedimentology. Allen \& Unwin, London.

Allen J (1973) A classification of climbing ripples cross-lamination. Journal of the Geological Society of London, 129: 537-541.

Allen J (1971) A theoretical and experimental study of climbing-ripple cross-lamination, with a field application on the Uppsala esker. Geografiska Annaler, 53: 157-187.

Allen J (1970) A quantitative model of climbing ripples and their cross-laminated deposits. Sedimentology, 14: 5-26.

Ashley G, Southard J, Boothroyd J (1982) Deposition of climbing-ripple beds: a flume simulation. Sedimentology, 29: 67-79.

Benn D, Evans D (1998) Glaciers and glaciation. Arnold, London.

Black R (1970) Glacial geology of two creeks forest bed, valderan type locality, and northern kettle moraine state forest. Wis. Geol. Nat. Hist. Surv, Inf. Circ, 13: 33-38.

Boone S, Eyles N (2001) Geotechnical model for Great Plains hummocky moraine formed by till deformation below stagnant ice. Geomorphology, 38: 109-124.

Brennand T (2000) Deglacial meltwater drainage and glaciodynamics: inferences from Laurentide eskers, Canada. Geomorphology, 32: 263-293.
Brennand T, Shaw J (1996) The Harricana glaciofluvial complex, Abitibi region, Quebec: its genesis and implications for meltwater regime and ice-sheet dynamics. Sedimentary Geology, 102: 221-262.

Brodzikowski K, Van Loon A (1991) Glacigenic sediments. Elsevier, Holland.

Carlson A, Mickelson D, Principato S, Chapel D (2005) The genesis of the northern Kettle Moraine, Wisconsin. Geomorphology, 36: 365-374.

Church M (1972) Baffin Island sandurs: a study of Arctic fluvial processes. Geological Survey of Canada, Department of Energy, Mines and Resources, Bulletin 216.

Church M, Gilbert R (1975) Proglacial fluvial and glaciolacustrine sediments. In Jopling A, McDonald B (ed.) Glaciofluvial and Glaciolacustrine Sedimentation. Society of Economic Paleontologists and Mineralogists, Special Publication. 23: 22-100.

Church M, Ryder J (1972) Paraglacial sedimentation: a consideration of fluvial processes conditioned by glaciation. Geological Society of America Bulletin, 83: 3059-3072.

Easterbrook D (1999) Surface process and landfor$m s$. Prentice Hall, New Jersey.

Evans D (2000) Quaternary geology and geomorphology of the Dinosaur Provincial Park area 
and surrounding plains, Alberta, Canada: the identification of the former glacial lobes, drainage diversions and the meltwater flood tracks. Quaternary Science Reviews, 19: 931$-958$.

Eyles N, Eyles C, Miall A (1983) Lithofacies types and vertical profile models; an alternative approach to the description and environmental interpretation of glacial diamict and diamictite sequences. Sedimentology, 30: 393-410.

Eyles N, Boyce J, Barendregt R (1999) Hummocky moraine: sedimentary record of stagnant Laurentide Ice Sheet lobes resting on soft beds. Sedimentary Geology, 123: 163-174.

Fahnestock R (1963) Morphology and hydrology of a glacial stream: White River, Mount Rainier, Washington. United States Geological Survey Professional Paper, No422A.

Fisher T, Taylor L (2002) Sedimentary and stratigraphic evidence for subglacial flooding, southcentral Michigan, USA. Quaternary International, 90: 87-115.

Fisher T, Taylor L, Jol H (2003) Boulder-gravel hummocks and wavy basal till contacts: products of subglacial meltwater flow beneath the Saginaw Lobe, south-central Michigan, USA. Boreas, 32: 328-336.

Folk R (1955) Student operator error in determination of roundness, sphericity, and grain size. Journal of Sedimentary Petrology, 25: 297$-301$.

Fraser G (1993) Sedimentation in an interlobate outwash stream. Sedimentary Geology, 83: 53$-70$

Hambrey M (1984) Sedimentary processes and buried ice phenomena in the proglacial areas of Spitsbergen glaciers. Journal of Glaciology, 30: 116-119.

Harrell J (1984) A visual comparator for degree of sorting in thin and plane sections. Journal of Sedimentary Petrology, 54: 646-650.

Hoper J, Szabo J (1993) Port Bruce ice flow directions on heavy-mineral assemblages in tills from the south shore of Lake Erie in Ohio. Canadian Journal of Earth Sciences, 30: 1236-1241.

Huddart D (1983) Flow tills and ice-walled lacustrine sediments, the Petteril Valley, Cumbria, England. In Evenson E, Schluchter C and Rabassa J, (ed). Tills and Related Deposits, Balkema: 151-168.
Johnson P (1975) Recent crevasse fillings at the terminus of the Donjek Glacier, St Elias Mountains, Yukon Territory. Quaestiones Geographicae, 2: 53-59.

Jopling A, Walker R (1968) Morphology and origin of ripple-drift cross-lamination, with examples from the Pleistocene of Massachusetts. Journal of Sedimentary Petrology, 38: 971984.

Karrow P, Paloschi G (1996) The waterloo kame moraine revisited: new light on the origin of some great lake region interlobate moraines. Zeitschrift Fur Geomorphologie, 30: 305315.

Krumbein W (1934) Size frequency distribution of sediments. Journal of Sedimentary Petrology, 4: $65-77$.

Miall A (1978) Lithofacies types and vertical profile models in braided rivers deposits: a summary. In Miall A (ed). Fluvial sedimentology, Canadian Society of Petroleum Geologists Memoir. 5: 597-604.

Mickelson D, Syverson K (1997) Quaternary geology of Ozaukee and Washington Counties, Wisconsin. Bull-Wis. Geol. Nat. Hist. Surv, 91: 15-29.

Munro M, Shaw J (1997) Erosional origin of hummocky terrain in south-central Alberta, Canada. Geology, 25: 1027-1030.

Nichols G (1999) Sedimentology and Stratigraphy, Blackwell Science, London.

Price R (1973) Glacial and fluvioglacial landforms, Oliver and Boyd, Edinburgh.

Punkari M (1997) Subglacial processes of the Scandinavian Ice Sheet in Fennoscandia inferred from flow-parallel features and lithostratigraphy. Sedimentary Geology, 111: 263-283.

Punkari M (1980) The ice lobes of the Scandinavian Ice-Sheet during the deglaciation in Finland. Boreas, 9: 307-310.

Rieck R (1979) Ice stagnation and paleodrainage in and near an interlobate area. Michigan Academician, 11: 219-235.

Santos J (2006) Genesis of the Kent Interlobate Moraine, Ohio. In Associação Portuguesa de Geomorfólogos (ed). Geomorfologia, Ciência e Sociedade, 3: 49-54.

Santos J (2003) Glacial geomorphology and sedimentology of the Kent Interlobate Complex, NE Ohio. Master's thesis, Kent State University, Ohio. 
Smith N (1985) Proglacial lacustrine environment. In Ashley G, Shaw J and Smith N (ed). Glacial Sedimentary Environments, Society of Paleontologists and Mineralogists, Tulsa: 135-216.

Sugden D, John B (1976) Glaciers and landscape. Edward Arnold, London.

Szabo J, Bruno P (1997) Interpretation of lithofacies of the Ashtabula Till along the south shore of Lake Erie, northeastern Ohio. Canadian Journal of Earth Sciences, 34: 66-75.

Szabo J, Totten S (1995) Multiple pre-Wisconsinan glaciations along the northwestern edge of the Allegheny Plateau in Ohio and Pennsylvania. Canadian Journal of Earth Sciences, 32: 2081-2089.

Szabo J, Keinath V, Munro-Stasiuk M, Miller B, Tevesz M (2006) Quaternary geology of the in- terlobate area between the Cuyahoga and Grand River Lobes, Northeastern Ohio. Ohio Department of Natural Resources, Division of Geological Survey, Guidebook No. 20.

Udden J (1898) Mechanical composition of wind deposits. Augustana Library Publication, 1: 69.

Wentworth C (1922) A scale of grades and class terms for clastic sediments. Journal of Geology, 30: 377-392.

White G (1982) Glacial geology of northeast Ohio. State of Ohio Division of Geological Survey, Columbus.

Zingg T (1935) Beitrage zur Schatteranalyse. Schweizerische Mineralogische und Petrographische Mitteilungen, 15: 39-140. 